\title{
Review
}

\section{Democracy and justice: Reading Derrida in Istanbul}

\author{
Agnes Czajka \\ Routledge, New York and Abingdon, 2017, vi+167pp., \\ ISBN 978-1138910645
}

Contemporary Political Theory (2018) 17, S150-S154. https://doi.org/10.1057/s41296017-0130-2; published online 29 June 2017

Although it is no longer common to dismiss Derrida's work as simply apolitical, more than a decade after his death there is little consensus about the exact contribution of deconstruction to political philosophy. In Democracy and Justice, Agnes Czajka aims both to explore Derrida's contribution to democratic theory and to use deconstructive thinking to help understand the struggle over democracy in contemporary Turkey. Her monograph is structured roughly in two, in line with her aims: Chapters 1 and 2 analyse key themes in Derrida's late political work; Chapters 3 and 4 discuss the recent history of Turkish politics, before elaborating the contribution that Derrida's thought might make to rethinking this debate. Specifically, she argues that Derrida's account of democracy as aporetic can contribute both to understanding the situation in Turkey and to rethinking theories of democratization more widely. Chapter 5 and the conclusion review the difficulties raised by this argument in order to underscore the force of justice, contributing to the debate over the normativity of deconstruction (see Hägglund, 2008; Haddad, 2013). The interest of her book lies in its attempt to develop a more immediately political reading of Derrida's treatment of democracy, whereas previous work has tended either to review his broader philosophical commitments in light of the more explicit political writings, or to understand those later interventions as refinements of his larger project.

Czajka's overview of Derrida's political thought begins with a brief account of deconstruction, understood as the 'disclosure of différance as the "non-essential essence" of identities, structures and systems' (p. 18) and hence as a form of ethico-political critique. Deconstruction is connected to democracy as the political regime with the greatest affinity to this practice of disclosure, which leads to a partiality towards certain strands of the modern democratic tradition: 'Derrida's democracy is, for instance, defined less by popular sovereignty, equality and majority rule than by free speech, openness to criticism and otherness, and

(C) 2017 Macmillan Publishers Ltd. 1470-8914 Contemporary Political Theory Vol. 17, S3, S150-S154 www.palgrave.com/journals 
hospitality to singularity' (p. 22). While this may not be a neutral characterization, and in other hands has been a basis for the suggestion that deconstruction is more committed to liberalism than to democracy (Brown, 2009), Czajka later suggests that there are resources in deconstruction for addressing these questions, perhaps even grounds for considering Derrida a radical democrat (pp. 55-59).

On the basis of this account of the relationship between deconstruction and democracy, Czajka turns to explore the aporias characteristic of modern democratic regimes, organizing her discussion around the idea of auto-immunity. As the condition of any identity, différance enjoins constitutive tensions between its openness and closure, the persistence of which will be coextensive with its survival. Processes of auto-immunization, she suggests, might be conceived as 'the materialization or operationalization of the différance unearthed by deconstruction' (p. 39). From this it follows that Derrida's own analyses of specific political conjunctures events in Algeria, and in the USA following 9/11 - might be understood as examples of second-order deconstructive analyses - critical interpretations of current events that reveal the workings of the underlying structures first-order deconstructive arguments reveal. As throughout her account of Derrida's thinking, Czajka's discussion of the difficulties raised by these interventions covers familiar ground but is nuanced and well-informed.

The three specific aporias which Czajka analyses relate to sovereignty, freedom and calculability. To sum up rapidly: democracy allows for sovereignty to be shared more fully and in more diverse ways than do other regimes, but democratic authority still depends on sovereign identity; democracy permits greater freedom than other regimes, but risks subsiding into anarchy; and while democracy promises equality, this must always be limited in practice. Relatively undeveloped at this point in the book, the latter aporia (calculability) is clarified through the subsequent discussion of justice as referring to the ways in which, despite formal equality, democratic states restrict goods to some citizens rather than others and may reterritorialize politics on ethnic or civic identities. One reservation here might be whether the issue of calculability could be connected more directly to questions of democratic theory and procedure, discussed in its final section, than the chapter allows.

Chapter 3 offers a detailed discussion of the rise of political struggles in Turkey since 1997, focusing on the Gezi Square protests in 2013. This is the point at which the ambivalent democratizing project of Erdoğan's AKP is itself challenged by a radical democratic counter-politics, and through its response reveals itself to be overtly authoritarian in character. The value for Czajka of an aporetic account of democracy is that it allows for a complex discussion of the degree to which both sides rely on 'competing articulations of democracy' (p. 96), and challenges the prevalent tendency to frame Turkish political history within theories of democratization. Theories which depend on the opposition of democracy to authoritarianism must characterize a state like Turkey in terms of a hybrid or mixed regime. From Czajka's alternative, deconstructive point of view, this hybridity better

(C) 2017 Macmillan Publishers Ltd. 1470-8914 Contemporary Political Theory Vol. 17, S3, S150-S154 S151 
illustrates more general features of any democratic regime as always characterized by struggle over the 'inherent plurality and thus multiple meanings of democracy/ ies' (p. 73).

The most striking and provocative feature of Democracy and Justice emerges in Chapter 4. Czajka takes seriously two of the problems that have often been remarked in accounts of Derrida's political thought: that 'democracy-to-come' names the quasi-transcendental condition of any observable or historical political regime, leaving the question of normative judgement between different forms of politics both urgent and apparently suspended; and that an analysis which prefers some specific model of democratic politics will not do justice to the openendedness of auto-immune processes. Treating the conflict between Erdoğan and the Gezi Park protestors as a dispute over different interpretations of the democratic inheritance, she suggests that different forms of politics must be more or less open to the aporetic nature of democracy and that this alone can provide the basis for identifying the more just alternative. In exerting its sovereign power, and in claiming to speak for a purportedly unified people in order to depict its opponents as traitors, the AKP under Erdoğan seeks to 'cure' (p. 104) democracy of its aporetic nature. In contrast, the protestors become exemplary of the fugitive character of deconstructive democratic action on the basis that the figure of the people in whose name the protests are presented is left radically open, and because in practical terms the membership of the group and their political demands are more open to difference.

Turning to the question of justice in Chapter 5, Czajka is keener to press the normative and the radical claims of Derrida's work than I would be. The figure of auto-immunity is ambivalent - it characterizes both the openness and closure of a self as potentially threatening to its integrity and survival. So a tendency in one direction or another may be either a function of the normal regulation of the self, or the dangerous expression of the auto-immune structure: if deconstruction asks us to think this co-presence as a non-dialectical tension, it cannot also provide grounds on which to identify one or other movement as having more than a provisional privilege from the point of view of its survival - here, the future of democracy in Turkey. This is what gives rise to the characteristic double binds of deconstructive thinking - no singularity without relation and alterity, and no equality without suppression of difference; no unconditional justice without conditional laws, hence no unmediated expression of the unconditional, only a struggle of law against law. Because justice, for Derrida, is the impossible, democracy-to-come cannot be an ideal at which we can aim. Czajka knows this, yet her account of justice still tends to reintroduce a teleological conception of a 'just democracy' in relation to which 'just acts' are understood to be oriented.

These points need not disqualify Czajka's careful and revealing interpretation of events in Turkey - but it suggests that this second-order interpretation, made in light of first-order deconstructive principles, can neither prove nor disprove those 
principles. However, I wonder whether it may be possible to form stronger criticisms of Erdoğan in the language of rights and freedoms and thus with reference to specific traditions of legal and political thought, than through an account of his suppression of democracy itself - not least because the term democracy must also refer to those rights and freedoms, established, however precariously or ambivalently, as international norms precisely through that history. This is one of the reasons why a first-order/second-order model of deconstructive thought may be problematic, although I should note that these terms are mine, introduced to clarify my explanation of Czajka's argument and its implications.

I underline the question of justice as the paradox or impossibility of respecting both equality and singularity at once, because this seems to me closer to the centre of Derrida's political thought than what Czajka sees as a community of singularities. Here her account tends to conflate his approach with that of other thinkers commonly invoked by the post-structuralist left, where making distinctions might allow greater precision: '[Derrida] thus attempts to think community along the lines of "inoperative" or "unavowable" community; a community without community; a "community of those without community"; or indeed a community of singularities or whatever beings' (p. 109). Politically, Czajka seems more strongly invested in her second aporia than the third; in her lively characterization of the roguishness and plurality of democratic political life rather than the legal framework through which the conditional laws of a state embody (and inexorably fail to meet) the standard of unconditional justice. Although her analysis is subtle and certainly recognizes the mutual implication of political action with the question of inheritance, it is drawn towards the anarchist temptation of seeing deconstruction as better embodied in intermittent interruptions of politics, as the passing comparisons to Rancière and Wolin (p. 72) suggest, than in the stability of institutions. This may limit the extent to which her argument can be generalized from its case study.

Although Czajka is sensitive to many of the double binds characteristic of deconstructive ethico-political thought, Democracy and Justice neglects the problem of institutions and right, without which her account risks presupposing the priority of the individual to the state, privileging anti-systemic movements, and preferring the militant or activist to the bureaucrat, judge or citizen. Yet one of the significant things that Derrida's account of différance has done is to clarify the distinction between the thought of difference, and a mere preference for difference, making it much harder to slip from one to the other.

\section{References}

Brown, W. (2009) Sovereign Hesitations. In: P. Cheah and S. Guerlac (eds.) Derrida and the Time of the Political. Durham, NC: Duke University Press.

(C) 2017 Macmillan Publishers Ltd. 1470-8914 Contemporary Political Theory Vol. 17, S3, S150-S154 S153 
Haddad, S. (2013) Derrida and the Inheritance of Democracy. Bloomington: Indiana University Press. Hägglund, M. (2008) Radical Atheism: Derrida and the Time of Life. Stanford: Stanford University Press.

Alex Thomson

University of Edinburgh, Edinburgh EH8 9YL, Scotland, UK alex.thomson@ed.ac.uk 